\title{
TRABALHO E SOCIABILIDADE \\ PRIVADA: A EXCLUSÃO DO OUTRO \\ Um olhar a partir das células \\ de produção
}

\section{Leonardo Mello Silva}

\section{Introdução}

O trabalho assalariado tem sido associado, na modernidade ocidental, à questão social e à incorporação de massas de trabalhadores à arquitetura regulatória do Estado, abrindo o caminho para o reconhecimento dos direitos coletivos e sociais. Esses direitos funcionaram por muito tempo como quadro de referência para o conjunto da população pobre e passaporte para a obtenção de uma condição de segurança em termos de modo de vida, na medida em que conjurava relativamente os acasos e as intermitências associados ao trabalho ocasional

* Colaborou a bolsista Vanessa Orban A. Santos (Pibic-CNPq). nas cidades, fosse ele qualificado ou não. A disciplina no uso da força de trabalho na fábrica moderna correspondia a uma certa previsibilidade na condição de emprego do operário ou operária, o que alimentava também formas determinadas de ação coletiva, associadas simultaneamente à resistência e a expectativas utópicas de emancipação.

No momento contemporâneo, a crise de formas consagradas de organização do trabalho, do emprego, da estruturação interna das empresas, com reflexos em sua localização espacial e na própria definição de seus limites físicos, tem levado os estudiosos a identificar uma verdadeira mudança de paradigma no ambiente industrial, justificando a caracterização da época em curso como sendo pós-fordista. Sem entrar no debate especializado sobre o significado desse termo, é suficiente reter de uma tal caracterização o diagnóstico de uma mudança estrutural que afeta, de maneira coerente e integrada, os vários elementos que compõem a regulação do trabalho assalaria- 
do e, portanto, a própria existência da classe social, definida em sua concepção clássica.

$\mathrm{O}$ aspecto a ser explorado no presente artigo está relacionado à experiência dos trabalhadores afetados pelas modernidades gerenciais aplicadas por empresas atingidas pelo processo de reestruturação industrial. Essas mudanças têm implicações importantes para a sociabilidade do grupo operário. Enquanto a identificação de classe associada ao que poderíamos designar como "velha questão social" está carregada de um conteúdo coletivo e com potencial de universalização, o novo desenho organizacional do trabalho enfatiza a participação diferenciada da força de trabalho e solicita cada vez mais o engajamento individualizado desse contingente. Se as literaturas sociológica e historiográfica recentes sobre classes sociais e o mundo do trabalho, em suas análises e narrativas, têm acentuado as clivagens geracionais, de gênero e raça, não deixa de ser também verdadeiro que o próprio processo de trabalho, em seu formato atual flexível, conspira para a fragmentação e o seccionamento do coletivo operário, sendo, dessa forma, igualmente uma fonte potente de clivagem e segmentação. Mais do que simplesmente fragmentar e dividir, a conseqüência última da aplicação de novos modelos produtivos testados pelas empresas é também o de excluir, isto é, afastar as linhas de força tendentes à conformação de uma identidade coletiva de grupo e incitar, ao contrário, aquelas tendentes a difundir em cada participante um comportamento instrumental e emulativo de tipo possessivo-aquisitivo.

Além disso, em vez de aparecer como uma imposição autoritária de níveis hierárquicos da empresa sobre os seus subordinados, os novos modelos procuram deixar à discrição do próprio grupo as decisões disciplinares (em maior proporção) e produtivas (em menor proporção), baseados em pressupostos delegativos e de autonomia do trabalho. A intenção deste artigo é discutir criticamente tais pressupostos, tendo por âncora uma pesquisa efetuada a partir de visitas e da observação direta do processo de trabalho de duas empresas do ramo de confecções na Região Metropolitana de São Paulo, entre 2001 e 2005. O formato de gestão do trabalho utilizado por ambas as empresas é conhecido por "células de produção". ${ }^{1}$
O texto está montado da seguinte maneira: a primeira seção expõe rapidamente o problema, o que envolve uma digressão sobre os modelos produtivos alternativos ao taylorismo-fordismo; discute a disjunção entre ruptura e continuidade, associada àquela periodização, e apresenta a pesquisa, descrevendo o processo de obtenção dos dados que oferecem o suporte para a discussão feita adiante. Na segunda seção é feita uma análise do contexto no qual se inserem as células de produção e o trabalho em grupo. A terceira seção organiza-se segundo os tópicos mais importantes encontrados nos casos estudados, tendo por fio orientador as características mais salientes desse modo de organização do trabalho, evidenciadas pela literatura da área. Uma confrontação entre essas características e os achados de campo percorre todo o texto. Por fim, em uma seção conclusiva faz-se o balanço dessa confrontação.

\section{O problema}

O debate sobre modelos produtivos - o taylorismo e o fordismo e suas alternativas - opunha idealmente dois conjuntos com características mutuamente exclusivas: produção rígida versus produção flexível, produção de bens discretos versus produção em massa, produção em esteira ou linha de montagem versus produção em módulos simultâneos. No entanto, essa estilização revelou-se pouco útil. A observação de casos concretos mostrou antes a convivência e a complementaridade desses princípios dicotômicos, tanto dentro de uma mesma unidade (onde seções mantinham um perfil "antigo", ao passo que outras aplicavam mais estritamente os ditames da produção enxuta), como ao longo da cadeia de clientes e fornecedores, em que empresas se especializam em partes ou componentes do produto final, marcada ademais por forte heterogeneidade organizacional, tecnológica e social. A noção de "fluxo" parece ser mais adequada para captar essa forma de racionalização do processo de trabalho que dosa elementos de ambos os modelos produtivos, o que demonstra também o seu potencial em termos de flexibilidade. Retirando boa parte de sua lógica interna do toyotismo ("modelo japonês"), o fluxo produtivo deve antes de tudo estar sempre em funcionamento, ${ }^{2}$ exigindo 
para a sua manutenção adequada a mobilização permanente do trabalho a ele associado. O fluxo é tenso porque obedece muito estritamente aos movimentos do mercado. Por outro lado, a mobilização permanente do trabalho toma a feição de uma responsabilidade coletiva. A "polivalência" atesta essa interdependência de intervenções produtivas que misturam tarefas bem definidas com manutenção de máquinas, zelo pela qualidade e prontidão diante de possíveis panes e desbalanceamentos. A rigor, o "trabalho" como um qualificativo bem demarcado pela tarefa (no sentido taylorista do termo) dilui-se, em certa medida, em favor do trabalho coletivo de manutenção do fluxo pelo menos em sua versão mais bem acabada.

O sistema organizacional, tal como é concebido, conecta ao mesmo tempo diferentes máquinas e segmentos da produção a diferentes atividades, e com isso força a uma interação entre os operadores dedicados a cada uma delas separadamente. No nosso caso, as várias especialidades do corte e da costura (galoneira, máquina reta, overloque etc.) - exceto para o caso do corte de tecidos na fábrica de capas automotivas, que é mantido como uma tarefa masculina apenas cruzam-se nas células, mesmo que a intercambialidade de uns postos com os outros não seja observada na prática - ao contrário, a persistência da qualificação do posto denuncia a continuidade entre paradigmas produtivos, discutida mais acima. A polivalência (ou multifuncionalidade) entre operadores é o reconhecimento do caráter interdependente dos trabalhos no novo formato produtivo, ao mesmo tempo em que aproveita os recursos de dentro, sem precisar contratar novos contingentes no mercado de trabalho. A forma organizacional que uma tal polivalência assume é a do trabalho em grupo. As células de produção são uma modalidade de trabalho em grupo. Cada célula fica encarregada de um conjunto de máquinas, a qual corresponde, por sua vez, a um segmento do processo (por exemplo, cuecas "sambacanção", cuecas slip; ou ainda, no outro caso, bancos traseiros de uma determinada marca de automóvel etc.). As variações do produto final, no caso do setor de confecções, não exigem uma diferenciação muito pronunciada entre os segmentos, as mudanças de produto podendo ser alcançadas no interior de cada segmento, por meio da mudança do tecido, do corte, da emenda etc., e não das máquinas propriamente.

A estratégia da pesquisa dividiu-se em três fases. Na primeira, foram feitas visitas a duas fábricas de confecções: uma de cuecas, localizada em um antigo bairro industrial da cidade, ${ }^{3}$ outra de capas de assentos de veículos automotores, localizada em um município limítrofe à zona leste da cidade. As visitas permitiram conhecer o processo de produção de ambos os produtos, bem como o desenho das células ${ }^{4}$. Em seguida, foram aplicados questionários fechados com perguntas sobre a atividade de trabalho, a avaliação do sistema organizacional em relação ao sistema anterior (produção "em linha") e informações gerais sobre o tempo de emprego. As respostas foram importantes para orientar o repertório de questões a ser explorado na terceira fase, de entrevistas abertas realizadas no próprio domicílio das costureiras. De fato, essa última fase foi adequada ao objetivo da investigação e também a mais rica em termos das evidências coletadas, pois elas permitiram o entendimento das mudanças organizacionais nas fábricas desde o ponto de vista daqueles que, em certo sentido, são o objeto das mudanças, isto é, as próprias trabalhadoras.

O ramo de confecções compreende atividades basicamente de corte e costura e é tradicionalmente um setor feminino. Nas fábricas estudadas, a divisão sexual de tarefas é nítida: os homens estavam alocados na seção de corte (no caso da fábrica de capas automotivas), ou então em serviços de apoio - manutenção mecânica e elétrica -, sendo que nesse último caso a convivência com mulheres em uma mesma célula é raramente observada (fábrica de cuecas).

A consideração da inovação organizacional vista "de baixo" desorganizou determinadas percepções de senso comum sobre o significado das mudanças no processo de trabalho, vistas como exigências da globalização e da modernização produtiva. Ela permitiu, por exemplo, situar dentro de um quadro de inteligibilidade coerente o juízo sobre as células, que é mais crítico do que supõe um visada superficial, ao mesmo tempo em que não é avesso a esse determinado sistema de trabalho. Na verdade, as células não são um marco significativo dentro da experiência de trabalho das informantes, embora o seja para sociólogos e inves- 
tigadores interessados com as mudanças paradigmáticas do mundo do trabalho. Esse descompasso, que à primeira vista poderia parecer decepcionante, foi revelador ao mostrar que muito caminho ainda está por ser trilhado no rumo de um entendimento mais completo de um fenômeno aparentemente esgotado, como é o efeito da reestruturação produtiva sobre o trabalho.

\section{Auto-regulação do grupo e o ardil da autonomia do trabalho}

Nas formas clássicas do conflito de classes do capitalismo dentro da produção, quer seja em seu formato concorrencial, quer seja monopolista, a oposição entre os subordinados e os níveis hierárquicos marcava uma diferença entre um grupo (operários) e um outro grupo menor (encarregados, supervisores, contramestres etc.). A luta pelo poder entre esses dois grupos anunciava a promessa de mudança social. Vejamos como se passam as coisas nos sistemas de produção baseados nos programas de qualidade.

O sistema de organização celular aparece no discurso das empresas como um contraponto ao sistema de produção "em linha", isto é, às características do modelo taylorista-fordista: rigidez dos equipamentos, cadeia de montagem, classificação funcional dos postos de trabalho, divisão do trabalho entre concepção e execução. No entanto, o controle do tempo de execução das tarefas persiste. O formato da organização celular das fábricas pesquisadas baseia-se no princípio da "linearização da produção" implementado pela indústria japonesa, e não na experiência dos grupos semi-autônomos suecos, em que o tipo de racionalização é diferente. ${ }^{5}$

A fábrica de cuecas segue o modelo da chamada "manufatura em U", onde máquinas semelhantes estão dispostas seqüencialmente numa ordem que lembra o desenho da letra "U", permitindo a redução do tempo "em curso" entre as peças e produtos semi-acabados, até o produto final. Cada conjunto de máquinas em forma de "U" é considerado uma ilha de produção. Uma célula compõe-se, por sua vez, de várias ilhas.

$\mathrm{Na}$ fábrica de capas automotivas, a disposição das máquinas é diferente. Não existem ilhas, e as células mais destacadas (duas) ficam uma diante da outra, sendo que uma esteira no meio recolhe os produtos prontos e os conduzem para um cesto, o qual segue para o estoque. As variações de produto não exigem mudanças de máquinas, mas de tipos de corte, dobra, tecido, emenda etc.

As características organizacionais associadas ao modelo da manufatura celular são bem conhecidas, pois fazem parte do repertório da "produção enxuta" ou do "toyotismo": preocupação com o desperdício; ausência de estoques ou, então, a manutenção de um patamar mínimo de estoques; busca incessante de qualidade; possibilidade de confecção simultânea de mais de um produto, aproveitando a ociosidade das máquinas; polivalência ou multifuncionalidade dos operadores, agregando tarefas antes alocadas ao pessoal de apoio; ênfase nas sugestões de melhorias; reuniões periódicas das células.

Na fábrica de cuecas, uma das razões para o sentimento compartilhado de que "antes era melhor" - o sistema de linha com características tayloristas, em vez do sistema atual, celular - está na existência do prêmio (bônus) pelo alcance de metas de produção. O sistema de trabalho em linha era nomeado como "individual" e o prêmio, quando havia, era contabilizado individualmente. Já o sistema de células, ao contrário, aparece como coletivo. As costureiras preferem o primeiro ao segundo.

Na fábrica de capas automotivas não há prêmio. Em ambos os casos, contudo, existe uma queixa generalizada contra o ritmo intenso de trabalho. Na enquete levada a efeito entre as operárias das duas fábricas, o ritmo intenso aparece como um dos principais aspectos negativos da organização do trabalho (59\% na fábrica de confecção de cuecas e $30 \%$ na fábrica de confecção de capas automotivas), ${ }^{6}$ juntamente com outros aspectos que reforçam a mesma percepção (22\% das trabalhadoras na fábrica de confecção de cuecas queixaram-se de que em toda a hora há mudanças de produtos; $54 \%$ na fábrica de capas automotivas disseram que a preocupação em errar é maior do que antes).

No prêmio, a vinculação da formação de salários com o trabalho em grupo - da mensuração baseada na produtividade individual para a mensuração baseada na produtividade da célula - 
expõe de maneira mais aguda o lado perverso da organização celular, quando vista da perspectiva dos que a experimentam. Só então fica claro o juízo compartido entre as costureiras de que o sistema de trabalho individual, em linha, era melhor. Mas, além da formação de salários, o foco de resistência pode ser detectado também na moldagem de uma sociabilidade imposta, com a conseqüente erosão das referências espontâneas de relacionamento entre as colegas e um maior peso da reflexão sobre a própria condição no grupo, sobrecarregando o sujeito e, em decorrência, afastando a operária de uma identidade coletiva, espelhada pela indiferenciação da classe.

Na fábrica de confecção de cuecas e na de capas, a maior parte das costureiras passou pelos dois sistemas (individual, primeiro; célula, depois): respectivamente, $66 \%$ e $76 \%$ das respondentes da enquete. As preferências pelo sistema individual referem-se a uma maior possibilidade de controlar o próprio trabalho e, portanto, o próprio rendimento. Quando a regulação se desloca para o grupo (com a sanção da encarregada ou supervisora), a norma de rendimento depende de um arranjo interno ao próprio grupo. Uma vez que o prêmio está indexado à meta fixada pela gerência para toda a célula, as próprias costureiras devem achar a medida de rendimento para alcançar a meta e, assim, embolsar o prêmio, que passa a ser uma referência para o rendimento no final do mês, uma vez que o salário-fixo é muito baixo. Várias "ilhas" competem entre si porque, para efeito do prêmio, vale a performance mais baixa: se, por hipótese, a primeira ilha alcançou os 100\% da meta e a segunda e a terceira conseguiram apenas $80 \%$, o prêmio da célula como um todo vai ser de $80 \%$ e não de $100 \%$. Isso implica em cobranças recíprocas, ao passo que no sistema individual o prêmio era administrado por cada uma, na medida em o hábito do trabalho repetitivo, paradoxalmente, permitia à trabalhadora ajustar os próprios limites e com isso "domar" aquelas resistências, conquistando assim um mínimo de previsibilidade na consecução laborativa da atividade.

Para os organizadores do trabalho, contudo, o sistema é mais transparente exatamente por assaltar os esconderijos individuais (ergonômicos inclusive) da produtividade, distribuídos e controlados coletivamente pelo grupo de trabalhadores, os quais operam mesmo dentro do formato da linha de montagem. Ao deixar exposto de maneira a mais direta possível a relação entre rendimento e resultado do trabalho, o sistema rememora a racionalidade tayloriana, em seu componente individualizante.

Vale lembrar da famosa experiência com o operário Schmidt, um homem bruto e de "mentalidade limitada", quando foi exposto ao método para fazer o carregador de lingotes de ferro (Taylor, 1987, pp. 54-59) levar 47 toneladas por dia no carrinho, em vez de 12 toneladas, como ocorria antes. Taylor perguntou ao operário se ele, Schmidt, era um homem "valioso", 7 ao que retrucou que não sabia o que isso queria dizer. Então, Taylor perguntou se ele gostaria de ganhar U\$ 1,85 em vez de U\$ 1,15 por dia, desde que seguisse rigorosamente as ordens do homem que lhe diria, a cada passo do processo de descarregar e carregar os lingotes, bem como de transportá-lo no carrinho, o que deveria fazer e como. Schmidt aceitou e concluiu: "Bem, então eu sou um homem valioso". Curiosamente, segundo o autor, se esse comportamento mercantilizado - expresso aqui pelo salário - se generalizasse no ambiente da seção ou da fábrica, ele acabaria minando a própria possibilidade de "colaboração" entre operários (ponto ressaltado em todo o discurso baseado nas filosofias da qualidade, hoje), pois quando o trabalho é realizado em grupo (Idem, p. 77) o operário perde a "ambição e a iniciativa":

Análise cuidadosa demonstrou que, quando os trabalhadores estão reunidos, tornam-se menos eficientes do que quando a ambição de cada um é pessoalmente estimulada; que quando os homens trabalham em grupo sua produção individual cai invariavelmente ao nível, ou mesmo abaixo do nível, do pior homem do grupo; e que todos pioram em vez de melhorarem o rendimento com a colaboração. Por estas razões foi expedida uma ordem geral na Bethlehem Steel Works que proibia trabalharem juntos, em grupo, mais do que quatro homens sem ordem especial do superintendente e que a permissão não podia ir além duma semana. (Idem, ibidem).

Assim, o trabalho em grupo realmente existente hoje esconde um componente individualizante, instaurando uma estranha compatibilidade 
entre os pólos antinômicos do coletivismo (veiculado no discurso gerencial) e do individualismo (observado na prática).

Mas isso não é tudo. O poder coletivo da célula pode eventualmente "premiar" o membro que, na opinião do próprio grupo, não se esforçou o suficiente, isto é, não deu "tudo o que pode" nesse caso indicando um rebaixamento individual do prêmio. Pode também, inversamente, "premiar" aquela, no caso as costureiras, que, embora pouco produtiva, demonstrou "força de vontade em ajudar", o que é reconhecido com a sua permanência na própria célula, em vez de ser transferida para a célula das "menos capazes" (associada a uma máquina mais "fácil" de operar), o que é prontamente estigmatizado pelo restante das costureiras. Em termos weberianos, a força de legitimação das células encontra-se abrigada muito mais do lado do "direito material" do que do "direito formal".

Há também um outro efeito do prêmio: ele acaba incitando a uma obrigatoriedade no relacionamento com o outro, no caso, a colega da célula. Assim, o outro pode aparecer antes como um fardo, em vez de ser um interlocutor em uma relação comunicativa. A constituição das células, aliás, não passa por nenhuma deliberação prévia do grupo. À parte as (escassas) especialidades (máquina reta, galoneira, overloque, colocação de perfil), o critério para juntar uma ou outra no mesmo grupo não parece obedecer a lógicas de amizade, vizinhança ou parentesco trazidas da esfera social para a esfera produtiva. No entanto, uma vez constituída a célula, a insegurança da aceitação pelo grupo passa pela performance produtiva individual - ou, então, por alguma forma de dom pessoal que compense aquele atributo objetivo (o que não foi observado em nossa pesquisa, isto é, alguém que tenha obtido a aceitação não pelas qualidades produtivas, mas outras, tais como simpatia, bom humor, convivialidade etc.).

\section{Autocontrole e exclusão}

O auto-controle não é apenas uma vigilância em torno da manutenção das quotas de cada operária para garantir o prêmio no final do mês. Ele leva no limite à exclusão do outro. Se o poder vem da célula, ela tem soberania para decidir sobre quem fica e quem sai. A encarregada ou supervisora "delega" essa função ao grupo. Com isso ela a um só tempo "lava as mãos" e desvencilha-se da suspeita de estar protegendo alguém. Enquanto o julgamento da encarregada ou supervisora pode ser "subjetivo", o julgamento do grupo não deixa margem à dúvida sobre a aceitação da colega que não segue ou não acompanha a norma de produção. Ele seria, assim, mais "objetivo" ou transparente - e também mais definitivo porque a operária excluída não tem a quem recorrer, dado o caráter peremptório de um julgamento feito por uma coletividade inteira, e não apenas de uma pessoa. Contra um é plausível recorrer; contra vários, fica mais difícil.

Ora, se o taylorismo gabava-se pela objetividade do método (the one best way), encontramonos diante de um tipo de racionalização que faz com que a objetividade do processo não seja vista como imposta de cima para baixo, mas antes como resultante "natural" da decisão soberana do grupo, isto é, em última instância dos próprios sujeitos, que, nesse caso, aceitam os constrangimentos apresentados pela firma: qualidade para o cliente, acesso a fatias maiores do mercado etc.

Não importa que a decisão se dê sobre um quesito disciplinar e não sobre um quesito técnico-econômico que ponha em questão as escolhas produtivas da firma. O princípio da solicitação da opinião (ou da decisão) já é um elemento novo em relação ao antigo modelo, baseado no controle estrito do trabalhador e na sublimação da iniciativa. Ele admite - mesmo dentro de campos pouco estratégicos para a empresa - a partilha do saber e, em tese, confirma a necessidade de compromisso (ou cooperação) entre o trabalho e os planejadores. Formalmente, a democracia nos locais de trabalho, que estava na boca da geração militante do novo sindicalismo, já está sendo exercida nas células. No entanto, ela conduz à exclusão, não à inclusão de seus "cidadãos". Se a célula é uma espécie de micro-Vontade Geral, seu modo de funcionamento expõe então uma faceta totalitária. Não existem direitos a que a parte possa invocar contra o bom senso do todo.

Nós fazemos uma reunião, com a menina participando da reunião, e a gente fala o que está acon- 
tecendo: ou ela melhora ou sai fora. Então, quando há o interesse da parte da pessoa, ela procura sempre melhorar, mas, quando não há, então a gente pede por favor para tirar, que troque (Trabalhadora de célula, empresa de confecção de cuecas. Depoimento em Mello e Silva, 2004, pp. 249-250).

Mais uma vez aparece o arbitrário do julgamento subjetivo.

"Se a gente vê que ela tá melhorando, que ela tá se esforçando, o que acontece? A gente procura ajudar. A gente corta o serviço, a gente arruma o serviço, depende da operação que ela faça. Mas se a gente resolver dar uma nova chance e a gente vê que ela não tá se esforçando, então..." (Idem, ibidem).

Se nos lembrarmos do que mostra Castel (1995), o direito do trabalho teve exatamente o papel de regular a parte subordinada (o trabalho) dentro da relação salarial. Agora, o discurso gerencial acena com a concessão de um alívio no velho estilo do controle direto - o que aparece em algumas interpretações como "consentimento ativo", "autonomia regulada" ou "implicação constrangida" -, e que, nos casos mais bem-sucedidos, desorganiza a auto-representação da classe como a parte subordinada naquela relação. Em outras palavras, embaralha a localização social antes clara entre o "nós" e o "eles", na formulação de Beaud e Pialoux (1999, pp. 35ss.).

Se antes a relação salarial recalcava as divisões da classe (entre qualificados e não-qualificados, entre homens e mulheres, entre estáveis e precários) em nome de uma positividade do indiferenciado e do indistinto, hoje a fratura da relação salarial destampa a caixa de Pandora das habilidades e das qualidades individuais. O operário (ou operária) não tem mais só de julgar o colega (para se certificar de que ele ou ela não vai prejudicar o rendimento do grupo), mas também a si mesmo (para se certificar de que ele ou ela é digno de estar no grupo). Essa pressão constante, que muitas informantes interpretam como stress, é fruto de uma situação objetiva de desregulação e de indeterminação que afeta a posição social da classe e joga a responsabilidade de construção de parâmetros coletivos para os próprios sujeitos.
Quanto mais esses parâmetros não se detêm em um nível generalizante e universalizável (como é o caso da relação salarial fordista) e caem para o nível das irredutibilidades individuais (trabalhador esforçado, diligente, relaxado, cuidadoso, grosseiro, tolerante, obsessivo etc.), mais frágil vai-se tornando a situação daqueles que os suportam. É por esse flanco que se insinua o discurso da competência ou das competências, o que no entanto não será abordado aqui. ${ }^{9}$ Os trabalhadores deixariam de se auto-representar como "subordinados" diante do poder da classe capitalista, passando a se ver como parceiros - e, no entanto, encontramse mais fragilizados.

A norma pública do direito do trabalho é conhecida. A norma privada da empresa é imponderável. Contra quem vai se queixar a costureira excluída? Contra as próprias colegas? Com que armas vai organizar a sua luta?

Relata a mesma informante:

Ela fica até o fim. Até que as colegas vêm e dizem: 'Olha, não dá mais'. É desagradável, mas se a gente tem a possibilidade de ter outra costureira que vá fazer a tarefa e que a gente vá ganhar, então é melhor. É melhor até para a companheira que vai sair porque ela não se sente humilhada. Ela sabe que a gente tá ganhando, ou melhor, que a gente tá deixando de ganhar por causa dela. Só que ela não tem aquele impulso de dizer 'olha, eu vou sair'. Então, há casos em que a pessoa às vezes até agradece a gente por ter tomado essa atitude (Trabalhadora de célula, empresa de confecção de cuecas. Depoimento em Mello e Silva, 2004, p. 251).

\section{A exploração da rebeldia}

Ajudar a colega que tem dificuldade em realizar o próprio trabalho é um dos pontos altos da solidariedade de seção, em qualquer situação, seja o grupo, seja a linha. O sistema de células, que na propaganda gerencial dá um peso considerável à superação da segmentação taylorista e à possibilidade de uma maior autonomia ${ }^{10}$ dos operadores diretos, conspira exatamente contra isso, porque todas as operárias têm que se preocupar com as próprias metas, e ajudar uma colega pode significar uma subtração da acumulação duramente 
construída. Deixar o próprio posto para dar uma "mão" àquela que está em dificuldade era paradoxalmente mais fácil no sistema anterior, pois o controle externo dava margem a certas fugas que o novo formato tende a gravar por intermédio de uma grande sobrecarga impingida a cada uma em particular. Se no caso da empresa de fabricação de cuecas, o prêmio é o principal instrumento que incita ao controle do grupo sobre a performance de cada costureira, na empresa de fabricação de capas, onde não existe o prêmio, o contínuo acúmulo de tarefas, que nunca permite um momento de descanso - fazer o papel da ajudante na embalagem, apresentar-se no corte do tecido com defeito, na pesquisa por um tecido de tonalidade semelhante, na preparação da máquina, na limpeza dela etc. - é o que afasta os pruridos humanitários que ainda podem subsistir nos juízos das operárias quando percebem alguém em apuros. Não há tempo! Se por acaso alguém se rebela contra o "sistema" e espontaneamente acorre para socorrer alguma colega que está visivelmente atrapalhada com a consecução da tarefa na máquina ao lado, esse impulso é imediatamente individual, reputado à "personalidade" da pessoa, já que a solidão em que se manifesta dificilmente o relaciona a um campo coletivo de forças. No entanto, esse impulso é tolerado - se é que ele é percebido pelo enquadramento intermediário, formado pelas supervisoras (duas para a seção de costura, em cada turno) e pelo agente da qualidade. A operária "rebelde", que lê no sofrimento da colega um traço perverso da organização, toma a iniciativa de lhe prestar ajuda, já que ela é produtiva, eficiente e por isso consegue terminar seu trabalho antes do que as outras; ela é capaz de fazer o seu trabalho e ainda arranjar tempo para trabalhar pela colega. Como os super-heróis, que salvam primeiro os outros e só depois si próprios, a operária rebelde se impõe mais essa carga, graças a seu gesto de nobreza. Com isso trabalha dobrado, intensificando seu próprio ritmo e ainda ajudando a manter o da colega - o que é orgulhosamente exposto para o interlocutor como uma vitória física (afinal, ela é jovem) e moral. Preenche assim, com louvor, a consciência íntima com o dever cumprido. E a produtividade da fábrica.

Talvez seja insatisfatório falar em desapropriação dos sentimentos individuais de injustiça e sua esterilização por conta da invisibilidade e do confinamento no qual eles se manifestam. Essa interpretação não capta a volta completa que é dada em torno das noções de autonomia, confiança, comunicação e deliberação ética do sujeito moral, que são definitivamente invertidas. É preciso levar a sério e atentar para a produtividade dos procedimentos postos em funcionamento por meio da dúvida e do conflito consigo mesmo: a reflexão que atormenta o sujeito e acaba deslizando para a classe - afinal, no exemplo do grupo que pensa e decide sobre a exclusão do outro está o exercício dessa reflexividade coletiva - mostra-se extremamente eficaz para a coerência do modelo de manufatura celular. Em pesquisas anteriores, ${ }^{11}$ explorando os modos de organização do trabalho baseados na qualidade, como o Total Productive Maintenance e outros, saídos todos da mesma fôrma do fluxo tensionado (Durand, 2003), já se tinha observado que o comprometimento do trabalhador passava pela ativação de disposições subjetivas que mobilizavam qualidades para as quais faltava uma norma muito precisa - empenho, investimento mental, abertura para o conhecimento, relacionamento positivo com os colegas etc. -, o que levava não só a uma grande arbitrariedade da parte do dominante (Durand, 2001), mas também a uma reação, da parte do dominado, que recusava o "envolvimento" por meio da invisibilidade e da discrição bem calculadas.

Dificilmente pode-se responder à questão de saber se a exploração da indignação moral da rebeldia faz parte ou não de uma estratégia de "reapropriação" por parte da empresa, ou seja, se os gerentes e a alta administração fazem isso de caso pensado. Não há nenhuma resposta que permita tal tipo de inferência. Ao contrário, nos relatos nunca aparece qualquer hostilidade aberta em relação aos patrões ou a seus representantes. Esses últimos tampouco parecem dedicados a algo mais do que a aplicação correta de um modelo disponível no mercado de consultoria organizacional. Creio que seja relativamente desnecessário perseguir esse tipo de resposta. É na naturalização do esforço de estar à altura de um bom julgamento de si e dos outros que reside todo o funcionamento da produtividade da fábrica. Com acréscimo de que esse bom funcionamento é extraído não do comportamento apático, mas exatamente do comportamento rebelde. Aí se encontra o elemento perverso, ponto de che- 
gada da torção das noções originais da crítica do próprio modelo. Só o trabalhador ativo interessa, não aquele que "não está nem aí".

Aliás, se nossa "heroína" Vanessa não jogar o jogo do salvamento, ela acaba contribuindo, no limite, para excluir a colega, pois esta, ao não agüentar o ritmo, acaba sendo demitida. Além disso, a comparação entre operárias com perfis opostos confirma a importância dos traços subjetivos para o campo de atração da empresa: Silvia, ${ }^{12}$ mais velha, trabalha há dezenove anos na fábrica de confecção de cuecas e com personalidade mais retraída, mal conhece a vizinha de alguns quarteirões (Jardim Carumbé, zona Noroeste da cidade de São Paulo), costureira da mesma fábrica; ${ }^{13}$ tímida, uma vida em segredo, fez toda a sua trajetória na mesma operação de máquina. Em contrapartida, Vanessa - a rebelde -, atirada e participativa, criou em pouco tempo de casa uma rede de amizades em torno do espaço de trabalho - exatamente o que as células ou os times de produção prescrevem. A saída de uma colega (na verdade, uma amiga), por não conseguir acompanhar o ritmo de produção, causou uma verdadeira decepção, quase uma mágoa, pela "falta" dela.

O consentimento ativo da força de trabalho, perseguido pelos aplicadores dos novos métodos de gestão do trabalho, não se manifesta apenas em procedimentos protocolares medidos por auditorias periódicas, mas sobretudo pela ativação de disposições subjetivas do tipo das discutidas acima. Pode-se observá-las em comportamentos de tipos diversos, que se misturam a traços psicológicos irredutíveis, ligados à constituição do "eu". Separar esses traços da personalidade social tem sido um dos papéis da relação salarial e da socialização que ela promove. ${ }^{14}$ Ora, os novos métodos de gestão, aproveitando-se do abalo na relação salarial (desemprego, mudanças nas qualificações, persistência da precariedade etc.) permitem um deslizamento da definição da atividade do trabalho cada vez mais em direção a atributos que sancionam a indistinção das esferas privada e pública. As empresas sob o novo regime de mobilização permanente dos assalariados têm operado uma vitória surda, talvez ainda pouco perceptível, sobre a consciência pública que até então preservava o espaço da vida familiar e dos interesses próprios da invasão estranha dos interesses do patrão. Vai-se tornando normal, na produção e nos serviços, o expediente de levar trabalho para a casa, assim como usar o espaço doméstico como treino para um manejo eficiente das chamadas boas práticas de fabricação. ${ }^{15}$

Podemos acompanhar, no discurso das informantes, o sentimento de autodenegação como um efeito do peso de ter de achar a própria medida do trabalho diante daquele das colegas: como saber se se está aquém ou além? Se é possível ser melhor? Se um dia se vai conseguir o rendimento ideal? No "empreendedorismo-de-si", esta é uma responsabilidade pessoal, para a qual todos os investimentos são mobilizados, de modo que a sensação de fracasso se mistura a uma derrota pessoal. Retração, vergonha e timidez, por um lado, ou certo otimismo desabusado, por outro, são os pólos subjetivos por onde oscilam as resultantes do embate do trabalhador com o seu meio, na falta de um parâmetro coletivo em que se possa expiar as dúvidas extremas: admiração exagerada ("fazer bem feito" requer mais do que técnica; requer talento, arte, dom), ou resignação exagerada ("jamais serei capaz de ser como fulana"). Isso não quer dizer que, entre as costureiras, por exemplo, não seja percebido claramente o estratagema da intensificação por obra da alocação sempre crescente de novas provações: a cada patamar alcançado como meta de produção, acrescenta-se mais um pouco para se testar até onde é possível chegar. Essa queixa demonstra que a consciência da exploração não está ausente. Falta, contudo, o apoio de uma baliza comum, espécie de âncora totêmica que esteja fora de cada uma delas; a certeza de que, separada dessa âncora, o desvio não é muito grave. A resistência ao estado de coisas, portanto, filtra-se na forma da indignação individualizada, fruto do dano corpóreo (cansaço, doença, acidentes) imediatamente identificado; ela dificilmente se converte, contudo, em uma resistência do grupo, porque faltam os processadores sociais que impeçam a incerteza dos juízos do trabalho de uma em relação ao trabalho das outras, o que dá ao mesmo tempo coesão e orientação. 


\section{Contar consigo mesmo}

O esforço de autoformação é um aspecto recorrente do mundo operário no ambiente pósreestruturação produtiva, em especial para a geração mais jovem. As costureiras das empresas pesquisadas confirmam esse dado. A preocupação em não ficar parada, em buscar sempre uma fonte de melhoramento que pode vir de conteúdos gerais ou específicos, de cursos direta ou indiretamente associados ao trabalho que se faz na fábrica, é um sinal de que os constrangimentos da escolaridade e do maior conhecimento necessário para manejar as novas máquinas e estar em dia com as exigências do ambiente são conscienciosamente percebidos. As respostas vêm com as iniciativas, sobretudo individuais, já que esse esforço não é sustentado coletivamente pela empresa.

Lá e cá, quando sobra tempo ou há um interregno na trajetória profissional, são procurados os cursos do Senai (entrevistada mais velha da fábrica de cuecas), ou cursos de computação e de inglês (Lúcia, da fábrica de capas automotivas). A relativa aleatoriedade das escolhas e a incoerência em relação ao tipo de trabalho efetuado em seus postos nas fábricas traem a insegurança quanto à real eficácia desses cursos para uma estratégia de enfrentamento efetivo (e preventivo) das vicissitudes do mercado de trabalho. Afinal, o horizonte funcional e profissional da costureira é limitado: não há para onde "subir" - galoneira, overloquista, máquina reta etc. -, as variações esgotam-se e a mobilidade em direção a uma função técnica é quase fora de cogitação, porque isso implicaria galgar competências propedêuticas, cujo handicap escolar atual dessa população praticamente proíbe. Por isso, tais cursos são também uma aposta em uma saída eventual para fora do universo da costura: nos serviços ou, quem sabe, como um patamar para um novo degrau de formação, que prossegue nesse caso como uma autoconfirmação da esperança de se achar qualquer coisa de melhor mais à frente.

Quando eu vi aqueles negócios lá dentro [referese às máquinas sofisticadas, com programação automática], eu falei para o meu marido: eu vou fazer um curso de computação. Aí fiz. Fiz lá no sOS Computadores [nome do curso]. Ele ainda foi comigo porque ele me dá o maior apoio. Tanto que ele queria que eu fizesse nutrição, que ele fala que nutrição é bom. Não sei (Vanessa, fábrica de capas).

Uma alternativa seria abrir um negócio próprio. A saída de trabalhar por conta ou ter a sua própria oficina é, no caso da costura, uma opção que sempre foi, por assim dizer, comum no universo popular que envolve esse tipo de trabalho feminino. Uma opção tradicional de famílias das classes trabalhadoras que acaba por se juntar à vaga recente de empreendedorismo e de opção pelo conta-propismo. Seria preciso, no nosso caso específico, em primeiro lugar desconectar o discurso e a prática disseminados como uma variante da crise da grande indústria fordista, por um lado, e, por outro, a situação desde sempre observada em termos de trabalho por conta-própria para esse ramo de atividade. Mas é evidente que a primeira tendência se sobrepõe também à segunda. Desde os anos de 1980 a realidade da conexão entre o trabalho de confecção e as formas de "terceirização" que então ganhavam espaço no tecido industrial foram bem apontadas. ${ }^{16}$ A conexão entre o trabalho efetuado pela unidade familiar e a grande indústria (na confecção, mas também no calçado e na agricultura) desenhava os contornos de uma cadeia produtiva que parecia confirmar a vigência do paradigma da flexibilidade. Mais recentemente, são o cooperativismo e as iniciativas produtivas individuais que parecem tomar o proscênio, tendo em comum com o discurso anterior o diagnóstico de crise irreversível do trabalho assalariado formal. Assim, vamos encontrar as costureiras usando do patrimônio secular da oficina no fundo do quintal, para "pegar a onda" do empreendedorismo, sair da fábrica ou - o que é mais comum a partir da observação de campo - manter as duas atividades, às vezes sendo subcontratadas por oficinas maiores (terceirização para cima), às vezes subcontratando outras costureiras, abaixo (nesse caso, quando são elas as "donas" do negócio). No entanto, o juízo acerca dessas saídas não parece ser o de uma adesão entusiasmada. Antes, parece mesmo de resignação diante da debilidade da opção assalariada, esta sim a escolha principal. 


\section{Os marcos regulatórios institucionais e seu significado}

Tanto na fábrica de cuecas como na fábrica de capas automotivas, o instrumento coletivo que lembra a existência do sindicato é a negociação da Participação nos Lucros e Resultados (P.L.R.). No primeiro caso, a P.L.R. cobre nada menos do que a negociação do prêmio, sendo, por isso, superimportante. No segundo, ela absorve itens nevrálgicos da agenda de qualidade e produtividade. Outro instrumento cada vez mais disseminado é o Banco de Horas. Ambos serão analisados a seguir.

Como um dos novos expedientes institucionais das relações de trabalho no Brasil, a P.L.R. deveria, segundo o espírito do legislador, favorecer a negociação coletiva e a relação direta (bipartite) entre patrões e empregados, sepultando desse modo o passado corporativista. Seria, portanto, um instrumento de modernização das relações trabalhistas. Nesse sentido, ela se mostra bastante compatível com o clima geral de modernização que envolve a empresa e o modo de execução do trabalho.

$\mathrm{Na}$ empresa de capas de veículos, a P.L.R. passou a considerar o retrabalho de peças um objeto de pontuação com vistas à obtenção de ganhos anuais por lucros e resultados. Com isso, ela incita à produtividade e intensifica o trabalho das costureiras. Tudo reside na definição do critério: o retrabalho considerado é apenas aquele que vem do cliente (produto recusado), não de dentro, isto é, de uma seção para outra (da máquina para a mesa de revisão). Isso reforça entre as operárias a mentalidade de vigilância permanente com a qualidade e de implicação com o destino das peças confeccionadas, como se o poder de sanção estivesse dentro e não fora do próprio local de trabalho. O mecanismo, que é recente - revelando uma suave evolução da medida regulamentadora em direção a um sentido marcadamente flexibilizante -, funciona da seguinte maneira: cada setor da fábrica tem uma quantidade de pontos para alcançar; estabelece-se uma cota de desperdício tolerada que é associada a uma escala de pontos invertida: 7,0 pontos é o máximo permitido; o índice de 0,0 pontos significa que a seção teve, segundo o jargão organizacional, zero desperdício. Em reuniões do grupo (da seção), ${ }^{17}$ as coor- denadoras expõem a pontuação até o momento e indicam quantos pontos faltam para atingir a quantidade estipulada como meta - o retrabalho entra como elemento de subtração dos pontos (por "retrabalho de peça").

Aumentava a quantidade de pontos para ver se a gente se esforçava mais para ver se não voltava peça! Quando aumenta o ponto é quanto o operário vai perder (Vanessa, fábrica de capas automotivas).

Isso também está relacionado com uma maior preocupação em fazer certo da primeira vez: "A cada cinco capas, olha-se 1 peça para ver se está dentro da conformidade" (Idem). Aumenta, também a preocupação em errar, ${ }^{18}$ juntamente com a agregação de novas tarefas de manutenção dos instrumentos. Antes de começar, por exemplo, há o set-up e depois, o check-list, que também consiste em uma inspeção da máquina. O set-up é para verificar se há algum ponto solto, e o check-list é para saber se está faltando algo na máquina. As supervisoras querem saber se de fato "[a costureira] fez o set-up ao invés de apenas escrever o set-up". Aumenta a responsabilidade da operadora. Não dá mais para pôr a culpa na máquina.

Antigamente se chegava, já ia costurando, não olhava nada. Depois que foi implantando esse ISO aí [mudou] (Idem).

Outro expediente da reforma das relações trabalhistas que faz parte do mesmo conjunto em que se insere a P.L.R. é o Banco de Horas. Destinado a possibilitar uma compensação dos momentos de pouca demanda com outros em que a jornada se estende, teve como conseqüência prática o fato de substituir o mecanismo das horas extras, que eram previstos estatutariamente e que significavam ganhos monetários para os trabalhadores. No novo formato, o trabalhador não ganha o "crédito" em dinheiro, mas em horas (tempo de trabalho). ${ }^{19}$

O Banco de Horas era bom porque tinha dias que precisava sair mais cedo, aí debitava no Banco de Horas. Mas, por outro lado, "perdia" porque tinha 
dias que entrava 6h e saía 9h da noite. Era preferível ganhar em dinheiro, não em horas (Idem).

O sentimento de perdas e ganhos, contudo, não é medido pelo metro do tempo, mas por aquele do dinheiro, o que afasta qualquer ilusão sobre o sucesso das estratégias de entropismo típicas das grandes corporações que aplicam o produção enxuta. Quando se trata de empresas pequenas ou médias, subcontratadas das grandes (a empresa de capas, por exemplo, fornece produtos para as principais empresas montadoras do país), os efeitos do fluxo manifestam-se muito mais como constrangimento do que como capacitação, o que afeta também a percepção de sua força de trabalho, a qual fica menos exposta às virtudes integradores e comunais reputadas da organização pós-fordista. As células - índice daquelas virtudes, por ativar a circulação de valores ligados à solidariedade de grupo, parceria e investimento emocional, em vez do vínculo instrumental apenas - experimentam, assim, uma situação de certa inadequação, relacionada à parcialidade de sua aplicação (valem antes de tudo para a obtenção de maior produtividade para a empresa).

A privatização das relações de trabalho pode ser constatada sob dois ângulos: primeiro, pela experiência da própria célula, que reforça o pertencimento à empresa, às expensas do mundo público; segundo, pela erosão da instituição clássica de representação do trabalho, o sindicato. Isso expõe a situação de desamparo político em que se encontram as operárias. Para 49\% delas, na fábrica de cuecas, o sindicato é distante na defesa das condições de trabalho e não dá muita atenção à base. Esse percentual sobe para $60 \%$ na empresa de capas automotivas. No entanto, institucionalmente ele existe, porque negocia a P.L.R. e o Banco de Horas. Como se não bastasse, seu papel é invocado não para impedir ou remediar os efeitos da organização celular, mas, ao contrário, para reforçá-la, na medida em que deveria, segundo o ponto de vista de uma das operárias, contribuir para que o rendimento salarial delas fosse maior (ora, diz a informante, "o sindicato não serve exatamente para isso: aumentar os salários?") por meio de um apoio resoluto ao prêmio, lutando por ele, ao invés de ser contra ele.
Dessa maneira, as fontes de um comportamento baseado no "empreendedorismo-de-si" encontram na organização do trabalho uma acolhida que dá coerência a práticas e a valores exercitados também extra-muros, como a abertura de um negócio próprio (por exemplo, uma oficina de costura no próprio domicílio) e a organização deste segundo o esquema cliente-fornecedor. A célula é uma fonte permanente de exclusão porque, como vimos, a luta para alcançar o prêmio (coletivo) passa pela incitação das colegas a ajustar seus ritmos (individuais) pelo padrão mais elevado. A costureira que não consegue alcançar o padrão não é bem-vista. O sindicato, portanto, ao ungir a célula e o prêmio que lhe corresponde, contribui indiretamente para minar um comportamento solidarista na produção. Isso é mais do que meramente confirmar a tão conhecida política desmobilizadora do sindicalismo pelego, "de carimbo", pois agora o sindicato é solicitado, pela sua própria base, a ser ativo e a entrar no jogo.

Por conta dessas e de outras mudanças, muitas costureiras - as que passaram pelos dois sistemas, em linha e em células - demonstram uma preferência pelo antigo modelo, tecnologicamente menos sofisticado e organizacionalmente mais tradicional. No primeiro, "o ganho dependia do esforço de cada um", ao passo que hoje ele "depende dos outros" (operária da célula n. 14, fábrica de cuecas). "É melhor trabalhar individual" do que em grupo, pois no primeiro caso, "cada um fazia a sua parte" (Idem). Esse sentimento é mais ou menos compartilhado pelas entrevistadas da fábrica de confecção de cuecas (onde há o prêmio).

\section{Significados da flexibilidade do trabalho}

Dentro do limite de uma mesma família de produtos, no interior da célula, uma operária pode fazer a operação da outra. Esse é o aspecto da flexibilidade da mão-de-obra no processo de trabalho associado, em uma versão mais "positiva", à polivalência dos operadores. Contudo, ele responde antes de qualquer coisa a dois constrangimentos bastante precisos: o absenteísmo e as lesões advindas da repetitividade dos gestos em 
uma única operação. ${ }^{20} \mathrm{~A}$ substituição imediata das costureiras faltosas demonstra inadvertidamente que ninguém é insubstituível, e que a qualificação não é suficiente para dificultar a rotação pelos postos da célula, já que as variações entre as máquinas e as respectivas operações requeridas por elas não são tão salientes. Por outro lado, a polivalência está estreitamente vinculada ao tipo de organização da produção, no sentido da possibilidade de manufaturar mais de um produto durante a mesma jornada.

$\mathrm{Na}$ fábrica de forros para o interior de veículos, como se trata de uma planta com poucos trabalhadores, as coordenadoras respondem diretamente à chefia, no caso, um supervisor de produção (com curso de nível superior) e um técnico da qualidade (com nível de $2^{\circ}$ grau). Na fábrica de confecção de cuecas, com contingente bem maior, as supervisoras também não encontram nenhum escalão intermediário, remetendo-se ao engenheiro de produção e, em menor medida (porquanto o poder de decisão quanto aos aspectos do funcionamento do processo produtivo parecem ser diminutos), à responsável pelos recursos humanos. Há reuniões freqüentes entre as coordenadoras e as integrantes das células, no estilo dos Círculos de Controle da Qualidade (porém sem essa designação), em que não só são discutidas questões referentes à produção e às melhorias no local de trabalho, mas também é estimulado o levantamento de sugestões por parte das operárias.

Tal como em outras fábricas que aplicam o sistema de manufatura celular, a publicidade dos resultados dos operários expõe para todos as diferenças de performance, isto é, quem é mais produtivo. Na fábrica de cuecas, é a célula, responsável pelo ajuste da produtividade do grupo e com base em parâmetros definidos no escritório de métodos, quem decide expor o desempenho individual. Na fábrica de capas automotivas, com apenas duas células, quadros em forma de papel tamanho ofício e ilustrado com gráficos, afixados pelo técnico da qualidade, contêm as informações acerca dos resultados da produção de cada costureira, a comparação entre as metas previstas e as metas alcançadas para o seu posto de trabalho, e ainda um índice de defeitos.

Existe um balanceamento entre o treinamento realizado na empresa, no exercício do próprio posto de trabalho (on the job) e o treinamento trazido de fora (elas teriam de "saber costurar"). O prato da balança pende cada vez mais para o treinamento adquirido antes de começar a trabalhar na fábrica, à medida que nos aproximamos do contingente mais novo em termos de tempo de casa. Isso fica evidente na fábrica de cuecas, pois na mudança para a nova planta (município limítrofe à cidade, zona oeste) contou bastante a contratação de novas trabalhadoras do local que tinham já passado por curso do Senai, em vez da manutenção das guardiãs do velho saber fazer, localizado nas instalações antigas de São Paulo. No entanto, o treinamento é muito importante quando se trata de "subir" dentro da empresa. Tanto na fábrica de capas automotivas quanto na de cuecas, as líderes (coordenadoras, primeiro caso; supervisoras, no segundo) são aquelas, dentre as costureiras, que seguiram a trajetória de treinamentos oferecidos. Mas isso não é tudo. A experiência conta também, isto é, conhecer todas as operações realizadas nas máquinas, mesmo que não de maneira empírica e direta. Além, é claro, de conhecer muito bem o maior número possível de operárias, ou seja, cultivar um bom relacionamento com as colegas do grupo, o que é facilitado pelo fato de a líder ter sido, ela mesma, operária como as outras. A posição da líder é ambígua porque, a despeito de cultivar alguns elementos de proximidade com as costureiras, a função de controle do trabalho e de disciplina das colegas, além da desenvoltura na circulação junto às chefias e seu papel de correia de transmissão das ordens vindas do planejamento da produção (o "bom relacionamento com o outro lado", muito enfatizado pela própria líder), faz com que ela, embora o tenha sido no passado, não seja mais considerada no presente como "uma delas".

\section{Conclusão}

A promessa de uma maior autonomia do trabalho, com os novos métodos de organização, revela-se uma armadilha. Umas contra as outras, mais auto-controladas do que nunca, tensas e cansadas, o exemplo das costureiras mostra os efeitos bastante práticos do desgaste do trabalho fabril. Há indicações de que tais efeitos são 
encontrados também em outros ramos industriais, assim como em outros tipos de atividade profissional, como os serviços. Na dificuldade de estabilização de um novo modo de regulação, tanto no centro como na periferia do capitalismo, repousa a indeterminação sobre as linhas de força a orientar a ação de grandes agregados sociais, como os assalariados da indústria. As formas de reprodução dos novos modelos produtivos disponíveis parecem prescindir, ao contrário, desses grandes agregados, jogando todo o peso na saída individual, no comportamento empreendedor que extrai a sua força da competição interna à própria classe, ali onde os processos de trabalho de antanho secretavam formas coletivas de ação - e de ação antagônica. Longe de incluir os assalariados em uma forma de vida, seja de matiz mecânica, seja de matiz orgânica, os métodos de organização do trabalho educam-nos para fora do social, ou seja, para o mercado. ${ }^{21}$

Os excertos retirados aqui e ali dos casos estudados, juntamente com os ecos de outros trabalhos de campo, indicam um caminho, uma tendência que se desenha: no prêmio salarial está a negação da sociabilidade fordista, a qual teve o seu ponto máximo, no Brasil, nas jornadas de greves que deram nascimento ao "novo sindicalismo". Foi ali o nosso momento de classe (1964-1980), correspondendo exatamente à consolidação de uma norma salarial entre as empresas montadoras de veículos, numa espécie de formação de salários coletiva do ramo (e que acabou por se chocar contra o Estado). Com o deslocamento da formação de salários para dentro da empresa, e como função do desempenho individual do trabalhador, o alvo muda: o poder de coação já não está mais no "outro", mas em si mesmo. É como se a "salvação", no sentido religioso, tivesse como única instância de certeza aquilo que se mostra pelas obras: a resultante é... trabalhar e trabalhar! O fracasso não é o produto de relações de força (exploração) objetivas, mas o indicador de uma culpa subjetiva, atribuída pelos outros ou até por si mesmo.

\section{BIBLIOGRAFIA}

ABREU, Alice \& SORJ, Bila (orgs.). (1993), O trabalho invisivel: estudos sobre trabalhado- res a domicílio no Brasil. Rio de Janeiro, Rio Fundo.

BEAUD, Stéphane \& PIALOUX, Michel. (1999), Retour sur la condition ouvrière. Paris, Fayard.

BRAVERMAN, Harry. (1981), Trabalho e capital monopolista. 3 ed. Rio de Janeiro, Zahar.

CASTEL, Robert. (1995), Les métamorphoses de la question sociale: une chronique du salariat. $1^{a}$ edição. Paris, Fayard. [Trad. brasileira: As metamorfoses da questão social: uma crônica do salário, Petrópolis, Vozes, 1998.]

DURAND, Jean Pierre. (2001), "O modelo da competência: uma nova roupagem para velhas idéias". Revista Latinoamericana de Estudios del Trabajo, ano 7 (14): 203228.

(2003), "A refundação do trabalho no fluxo tensionado". Tempo Social, 1 (15): $139-158$

(2004), La chaîne invisible. Travailler aujourd'bui: flux tendu et servitude volontaire. Paris, Le Seuil (col. Économie Humaine).

DURAND, Jean Pierre; STEWART, Paul \& CASTILLO, J. J.(1998), L'avenir du travail à la chaîne: une comparaison internationale dans l'industrie automobile. Paris, La Découverte.

HIRATA, Helena; FERREIRA, Cândido G.; MARX, Roberto; SALERNO, Mário S. (1992), "Alternativas sueca, italiana e japonesa ao paradigma fordista: elementos para uma discussão sobre o caso brasileiro", in Rosa M. S. de Melo Soares (org.), Gestão da qualidade: tecnologia e participação, Brasília, Cadernos Codeplan, 1.

MELLO E SILVA, Leonardo. (2004), Trabalho em grupo e sociabilidade privada. São Paulo, Editora 34.

TAYLOR, Frederick Winslow. (1987), Princípios de administração científica. 7 ed. São Paulo, Atlas. 


\section{Notas}

1 Outras designações para o mesmo formato são: "trabalho em grupo", "grupos de trabalho", "times" e "manufatura celular".

2 As idéias discutidas a partir desse ponto estão mais bem desenvolvidas em Durand (2003, 2004).

3 Posteriormente a fábrica deslocou-se também para um município limítrofe, dessa vez na zona oeste da cidade.

4 Para uma descrição mais detida, ver Mello e Silva (2004, cap. 4)

5 Para uma boa apresentação dessas diferenças, ver Hirata et al. (1992).

6 O percentual da população trabalhadora das duas fábricas que respondeu ao questionário em final de 2001 foi de mais da metade do contingente total de empregados, no caso da fábrica de cuecas, e a quase totalidade dos empregados da fábrica de capas automotivas, levando-se em conta que apenas foi possível aplicá-lo em 1 dos (dois) turnos de trabalho. A primeira contava, à época das visitas, com cerca de quatrocentos empregados; a segunda, com oitenta.

7 Na tradução da mesma passagem por Braverman (1981, p. 97).

$8 \quad$ Ver Durand et al.(1998).

9 Uma discussão um pouco mais detida a esse respeito pode ser encontrada em Mello e Silva (2004, pp. 55-93). Ver também Durand (2001).

10 Não pode existir autonomia diante de metas préestabelecidas por fora e acima dos sujeitos. Autonomia é, por definição, um atributo que pressupõe escolhas.

11 Essas pesquisas transcorreram entre 1995 e 1996. Uma pequena parte desses resultados, sem todas as suas implicações, é apresentada em Mello e Silva (2004, pp. 149-224), em que tais questões são discutidas, sobretudo a respeito da figura do líder.

12 Os nomes são fictícios.

13 É verdade que se trata de uma fábrica maior em comparação à de capas automotivas. Ver nota 6 supracitada.

14 Ver, a propósito, Castel (1995).

15 Good Manufacturing Practices é o selo de uma das várias modalidades de certificação da qualidade.
Uma resultante adicional da avaliação pela "competência" é que o estilo de avaliação profissional, típico dos "colarinhos brancos", para os quais as consultorias de gestão abundam em sua ênfase na "pessoa", mais e mais se aproximam dos chamados "operacionais", isto é, daquela população que a antiga sociologia industrial chamava de "colarinhos azuis".

16 Ver, por exemplo, Abreu e Sorj (1993).

17 Vê-se dessa forma que o significado do "trabalho em grupo" e dos espaços de reunião do grupo estão ambos diretamente vinculados a metas diretas de produtividade.

18 Uma das perguntas dos questionários, a propósito de quais eram os aspectos negativos do sistema celular, teve como resposta que "a preocupação em errar é maior" para 16\% na fábrica de cuecas, e $54 \%$ na fábrica de capas. O ritmo muito intenso foi apontado por 59\% das primeiras e 30\% das segundas como outro aspecto negativo. A combinação dos dois aspectos traça um quadro de inequívoca intensificação do trabalho devida ao modelo.

19 Além disso, com esse expediente, o empresariado joga com a variabilidade da mão-de-obra feminina, em função das demandas do trabalho doméstico.

20 Os dois constrangimentos são observados indistintamente nas duas fábricas, sobretudo LER (Lesões por Esforços Repetitivos), que aparece nas entrevistas e no acompanhamento feito pelo Centro de Referência em Saúde do Trabalhador da Regional da Secretaria Estadual da Saúde em São Paulo, onde se localizava originalmente a fábrica de cuecas.

21 A contraparte dessa operação des-socializadora é o desenvolvimento dos fundos de ações ou clube de acionistas formados pelos próprios trabalhadores, uma realidade que não se observou, contudo, nas empresas que foram objeto da presente pesquisa. Mas que pode ser uma realidade alhures. 


\section{TRABALHO E SOCIABILIDADE PRIVADA: A EXCLUSÃO DO OUTRO. UM OLHAR A PARTIR DAS CÉLULAS DE PRODUÇÃO}

Leonardo Mello Silva

Palavras-chave: Reestruturação produtiva; Organização do trabalho; Trabalho em grupo.

Este texto detém-se sobre uma modalidade de organização do trabalho denominada "células de produção”. O autor discute o contexto macrossocial em que elas se disseminaram na indústria e apresenta os resultados de uma pesquisa levada a efeito em duas fábricas de confecções, na Região Metropolitana de São Paulo. A partir da experiência de trabalho das próprias costureiras, o artigo pretende reinterpretar certos juízos emitidos pelo discurso gerencial a propósito de tópicos como polivalência, qualificação e flexibilidade. O ponto alto do modelo -auto-regulação pelo grupo - é também o momento de evicção do membro menos produtivo, o que, num âmbito mais geral, tem implicações para a solidariedade de classe. A esterilização das instituições clássicas de ação coletiva sob esse novo formato organizacional também é abordada. Por fim, o texto aponta para o fato de que experimentos como o das células de produção, por causa de seu pendor individualizante, minam a formulação típica da questão social em sua acepção moderna.

\section{WORK AND PRIVATE SOCIABILI- TY - THE EXCLUSION OF THE OTHER: A VIEW FROM THE "PRODUCTION CELLS" MODEL}

Leonardo Mello Silva

Keywords: Work organization; PostFordism; Flexibility; Production cells manufacturing.

This article deals with a particular kind of work organization, the so-called "production cells" model, and discuss the macrosocial context where they have grown in the industry sector. It presents the results of a fieldwork carried out within two plants in clothing manufacturing branches in the surroundings of São Paulo City. Its main purpose is to reinterpret some judgments concerning multi-tasking, skills and flexibility due to the administrative and management rationale in contrast to the ones coming from the sewing workers themselves. The cherishing point of the model - the self regulation by the group - is at the same time the moment where the less productive member is expelled from the cell group. That contradictory crossing of opposite strains is highlighted by the paper so as to emphasize the problematic quest for solidarity in terms of social class's scheme. The erosion of classical institutions for collective action - especially the ones related to capital and labor conflict - is assumed to grow in the tracks of that new model of work organization, to which we have to add also other aspects, such as the payment system, training and qualification requirements. In the end, the article points out that the individualization mood issued from production cells is hardly compatible with the typical stressing on 'social question' raised by the modern times.

\section{TRAVAIL ET SOCIABILITÉ PRIVÉE. L'EXCLUSION DE L'AUTRE. UN REGARD À PARTIR DES CELLULES DE PRODUCTION}

Leonardo Mello Silva

Mots-clés: Organisation du travail; Nouveau modèle productif; Post fordisme; Flexibilité.

Cet article porte sur une modalité d'organisation du travail qui s'appelle "cellules de production". Il aborde tout d'abord le contexte macrosocial dans lequel elle se déroule et, dans une deuxième partie, présente les résultats d'une recherche menée dans deux usines de confection situées aux environs de São Paulo. À partir de l'expérience de travail des couturières ellesmêmes, l'article se propose de réinterpréter certains des jugements portés par le discours managérial sur un tas de notions diffusées par le nouveau modèle productif, tels la polyvalence, la qualification et la flexibilité. Le point le plus cher du modèle - l'autorégulation par le groupe - est aussi le moment où l'ouvrière la moins productive est repoussée en dehors du collectif si elle n'accomplit pas le but établi par le groupe lui-même. Or, du point de vue plus large de la solidarité de classe, il s'agit d'un paradoxe : plus le système est efficace, plus il affaiblit l'identité collective. Si l'on ajoute à cela l'érosion croissante des institutions collectives liées au rapport capital x travail (tel le syndicat, par exemple), le constat de l'article mène à un diagnostic d'individualisation des relations de travail, qui détruisent la vigueur discursive et pratique de la 'question sociale', d'après l'acquis de la modernité. 